\title{
UJI EFEKTIVITAS INFUSA DAUN INSULIN (Thitonia diversifolia (Hemsl.) A. Gray) TERHADAP PENURUNAN KADAR GLUKOSA DARAH PADA MENCIT (MUS MUSCULUS) PUTIH JANTAN
}

\author{
Andy Brata*, Yossie Bella Pratiwi \\ Jurusan Farmasi Poltekkes Kemenkes Jambi, Indonesia \\ *Korespondensi penulis: andybrata@poltekkesjambi.ac.id
}

\begin{abstract}
ABSTRAK
Latar Belakang: Daun insulin merupakan salah satu tumbuhan yang memiliki kegunaan dari daunnya. Daun insulin memiliki kandungan flavonoid yang diduga bisa menurunkan kadar glukosa darah. Penelitian ini bertujuan untuk mengetahui efektivitas infusa daun insulin terhadap penurunan kadar glukosa darah pada mencit putih jantan yang diinduksi glukosa..

Metode: Penelitian ini merupakan penelitian eksperimen dengan rancangan Pretest-Postest with Control Group. Hewan uji yang digunakan adalah 25 ekor mencit putih jantan yang dibagi dalam 5 kelompok, yaitu kelompok kontrol negatif (Na-CMC), kelompok kontrol positif(Glibenklamid), kelompok infusa daun insulin $420 \mathrm{mg}, 840 \mathrm{mg}$, dan 1260 mg. Dilakukan pengamatan dan pengecekkan kadar glukosa darah mencit pada menit ke-30, 60, 90, dan 120.

Hasil: Hasil uji statistik One-Way ANOVA menunjukkan hasil signifikan pada menit ke-90 dan 120. Dilanjutkan dengan uji Post Hoc Duncan yang menunjukan dosis terbaik, yaitu dosis $420 \mathrm{mg}$ yang memiliki efek sebanding dengan Glibenklamid $5 \mathrm{mg}$, kemudian diikuti dengan dosis $1260 \mathrm{mg}$ dan $840 \mathrm{mg}$ yang sudah memiliki efek antihiperglikemia tetapi belum terlihat perbedaan.

Kesimpulan: Dosis infusa yang dapat menurunkan kadar glukosa darah adalah dosis $420 \mathrm{mg}$ dengan penurunan kadar glukosa darah maksimal pada menit ke-90 dan menit ke120.
\end{abstract}

Kata Kunci: daun insulin; Tithonia diversifolia (Hemsl.) A. Gray; glibenklamid; kadar glukosa darah

\section{EFFECTIVENESS TEST OF INSULIN (Thitonia diversifolia (Hemsl.) A. Gray) LEAF INFUSION ON DECREASING BLOOD GLUCOSE LEVELS IN MALE WHITE MICE (MUS MUSCULUS)}

\section{ABSTRACT}

Background: Insulin leaf is one of the plants that has the use of its leaves. Insulin leaves contain flavonoids that are thought to reduce blood glucose levels. This study aims to determine the effectiveness of insulin leaf infusion on decreasing blood glucose levels in male white mice.

Methods: This study was an experimental study with a Pretest-Posttest with Control Group design. Test animals used were 25 male white mice which were divided into 5 groups, namely the negative control group (Na-CMC), positive control group (Glibenklamid), insulin leaf infusion group $420 \mathrm{mg}, 840 \mathrm{mg}$, and $1260 \mathrm{mg}$. Observation and checking of blood glucose levels in mice in the 30th, 60th, 90th, and 120th minutes.

Results: One-Way ANOVA statistical test results showed significant results in the 90th and 120th minutes. Followed by the Duncan Post Hoc test which showed the best dose, ie a dose of $420 \mathrm{mg}$ which had an effect comparable to Glibenclamide $5 \mathrm{mg}$, then followed by a dose of $1260 \mathrm{mg}$ and $840 \mathrm{mg}$ which already have antihyperglycemic effects but no difference has been seen.

Conclusion: The dose of infusion that can reduce blood glucose levels is a dose of $420 \mathrm{mg}$ with a decrease in maximum blood glucose levels in the 90th minute and 120th minute.

Keyword: insulin leaves; Tithonia diversifolia (Hemsl.) A. Gray; glibenclamide; blood glucose level 


\section{PENDAHULUAN}

Diabetes Melitus (DM) adalah suatu kelompok penyakit metabolik dengan karakteristik hiperglikemia yang terjadi karena kelainan sekresi insulin, kerja insulin, atau kedua-duanya, ditandai dengan kadar glukosa darah yang melebihi normal (hiperglikemia) akibat tubuh kekurangan insulin, baik absolut maupun relatif. ${ }^{1} \mathrm{DM}$ dibagi menjadi 4 jenis yaitu DM tipe 1 yang merupakan defisiensi insulin akibat kerusakan sel beta, DM tipe 2 yaitu berkurangnya produksi insulin dari sel beta, DM tipe lain, dan DM gestasional. ${ }^{2}$

Penatalaksanaan DM dapat dilakukan melalui latihan jasmani dan terapi farmakologis yang terdiri dari obat oral, dan bentuk suntikan. ${ }^{2}$ Kekurangan dari terapi obat oral maupun suntikan yaitu harga obat yang tidak murah dan memiliki efek samping. Oleh karena itu banyak obat tradisional yang dipilih oleh penderita DM seperti daun insulin, salah satu tanaman obat yang bisa dimanfaatkan untuk mengobati penyakit diabetes. $^{3}$

Daun insulin (Tithonia diversifolia (Hems.) A.Gray) memiliki berbagai kandungan yang berperan dalam melawan radikal bebas, menginduksi sistem pertahanan stress selular serta kandungan tannin, flavonoid dan saponins yang banyak berpotensi dalam bidang farmakologi. ${ }^{4}$ Mekanisme kerja saponin yaitu dengan menghambat GLUT-1 sehingga menurunkan absorbsi glukosa. ${ }^{5}$ Flavonoid pada DM dapat menghindari absorbsi gula, menstimulasi pengambilan glukosa pada jaringan perifer, juga dapat bertindak seperti insulin dengan cara mempengaruhi mekanisme insulin signaling. ${ }^{6}$ Tannin dapat memicu metabolisme glukosa dan lemak sehingga timbunan dari kedua sumber kalori ini dapat dihindari. Tannin juga memiliki aktivitas hipoglikemik dengan meningkatkan glikogenesis. ${ }^{7}$

Berdasarkan penelitian yang dilakukan Mila Karmila Sri Setiomulyo ${ }^{8}$ didapat hasil, air rebusan daun insulin (Tithonia diversifolia (Hemsl.) A. Gray) dapat menurunkan kadar glukosa darah pada tikus yang terbebani glukosa. Dosis air rebusan daun insulin (Tithonia diversifolia (Hemsl.) A. Gray) yang dapat menurunkan kadar glukosa darah yaitu 3 g/kgBB tikus.

Berdasarkan penelitian tersebut disarankan untuk melakukan penelitian lanjutan tentang pengaruh infusa daun insulin dengan dosis yang berbeda. Sehingga peneliti tertarik untuk melakukan penelitian ulang dengan cara memvariasikan dosis infusa daun insulin.
Penelitian ini bertujuan untuk mengetahui uji efektivitas infusa daun insulin (Tithonia diversifolia (Hems.) A.Gray) terhadap penurunan kadar glukosa darah pada mencit (Mus musculus) putih jantan dan untuk mengetahui berapakah dosis infusa daun insulin (Tithonia diversifolia (Hems.) A.Gray) yang efektif sebagai penurun kadar glukosa pada mencit (Mus muculus) putih jantan.

\section{METODE}

Desain penelitian yang digunakan adalah metode eksperimental dengan rancangan Pretest-Postest with Control Group yaitu pengelompokkan anggota-anggota kelompok kontrol dan kelompok eksperimen dilakukan berdasarkan acak atau random. Kemudian dilakukan pretest pada kedua kelompok tersebut, dan diikuti intervensi pada kelompok eksperimen. Setelah beberapa waktu dilakukan Postest pada kedua kelompok tersebut. ${ }^{9}$

Hewan uji menggunakan mencit (Mus musculus) jantan dewasa yang mula-mula ditimbang berat badannya supaya diketahui apakah sehat dan cocok digunakan sebagai hewan uji atau tidak. Sebanyak 25 ekor mencit dengan berat badan 20-30 g dipilih dan dibagi dalam 5 kelompok yang terdiri dari masingmasing 5 ekor mencit pada tiap kelompoknya. Kemudian diadaptasikan selama 5 hari. Setelah hewan uji diperiksa dan dikelompokkan kemudian diberi tanda untuk masing-masing kelompok.

Hewan uji dipuasakan selama 8 jam dan diukur kadar glukosa darahnya sebagai kadar glukosa awal mencit. Setiap pengukuran kadar glukosa darah mencit dilakukan menggunakan glukometer. Kemudian mencit diinduksi larutan glukosa $15 \%$ untuk menaikkan kadar glukosa darahnya dengan volume $0,13 \mathrm{ml} / 20 \mathrm{~g}$ BB mencit. Setelah 30 menit lakukan pengecekan kembali kadar glukosa darah mencit.

Tahap selanjutnya setiap kelompok mencit mendapatkan perlakuan. Kelompok I sebagai kontrol diberikan air suling, kelompok II sebagai pembanding diberikan suspensi glibenklamid, kelompok III, IV, dan V diberikan Infusa daun insulin dengan dosis $420 \mathrm{mg}, 840$ $\mathrm{mg}$, dan $1260 \mathrm{mg}$. Pengamatan dinilai setelah pemberian perlakuan, dengan mengukur kadar gula darah pada menit ke 0, 30, 60, 90,dan 120.

Data yang diperoleh dari penelitian dianalisis secara statistik dengan uji ANOVA dan dilanjutkan dengan uji Post Hoc Duncan, yaitu untuk mengetahui perbedaan rata-rata antara dua variabel atau lebih dari dua variabel. 


\section{HASIL DAN PEMBAHASAN}

Hasil skala rata-rata uji penurunan kadar glukosa darah didapat data seperti tabel 1. Penurunan kadar glukosa darah masing-masing mencit pada tiap kelompok didapatkan hasil yang bervariasi. Data penurunan kadar glukosa darah mencit diolah menggunakan uji One-way ANOVA dengan tahap uji reabilitas, uji validitas, dan uji normalitas.

Data dikatakan reabilitas jika nilai pada kolom Cronbach's Alpha $\geq 0,6 .{ }^{9}$ Hasil uji realibilitas didapatkan Cronbach's Alpha 0,923 sehingga dapat dikatakan bahwa data tersebut realibel. Setelah itu dilakukan uji validitas, uji validitas dilihat pada kolom Corrected Item Total Correlation, jika nilai pada kolom tersebut $\geq$ 0,396 maka dapat dikatakan bahwa data tersebut valid. Pada uji validitas semua data mendapat hasil $\geq 0,396$, ini berarti semua data valid dan bisa dilanjutkan ke uji berikutnya. ${ }^{9}$
Hasil uji normalitas dapat dilihat pada kolom Asymp.Sig. (2-tailed), jika nilai $p \geq 0,05$ maka sudah normal. Berdasarkan data yang didapat, data tersebut sudah normal karena nilai $p \geq 0,05$ dan bisa dilanjutkan dengan menggunakan One-Way ANOVA dan dilanjutkan dengan uji post hoc Duncan. ${ }^{9}$

Hasil uji menggunakan One-Way ANOVA dapat dilihat dari nilai signifikan. Jika nilai $p \leq 0,05$ maka hasil dapat dikatakan signifikan atau berbeda nyata. Tetapi dari percobaan yang dilakukan hanya ada 2 data yang memiliki nilai $p \leq 0,05$, yaitu data pada menit ke90 dan data pada menit ke-120 (tabel 1). Pada menit ke-30 dan menit ke-60 belum menunjukkan hasil yang signifikan atau dapat dikatakan bahwa pada menit ke-30 dan menit ke60 sudah ada penurunan kadar glukosa darah, tetapi belum terlihat berbeda nyata.

Tabel 1. Hasil Pengukuran Rata-Rata Kadar Glukosa Darah dan Uji Penurunan Kadar Glukosa Darah Mencit

\begin{tabular}{|c|c|c|c|c|c|c|c|c|c|c|}
\hline \multirow{3}{*}{$\begin{array}{l}\text { Kelompok } \\
\text { Perlakuan }\end{array}$} & \multirow{3}{*}{ Puasa } & \multirow{3}{*}{$\begin{array}{l}\text { Setelah } \\
\text { induksi } \\
\text { Glukosa }\end{array}$} & \multicolumn{6}{|c|}{ Kadar Glukosa Darah Mencit (mg/dl) } & \multirow{2}{*}{\multicolumn{2}{|c|}{$\begin{array}{r}\text { Menit } \\
\text { ke-120 }\end{array}$}} \\
\hline & & & \multicolumn{2}{|c|}{$\begin{array}{l}\text { Menit } \\
\text { ke-30 }\end{array}$} & \multicolumn{2}{|c|}{$\begin{array}{l}\text { Menit } \\
\text { ke-60 }\end{array}$} & \multicolumn{2}{|c|}{$\begin{array}{l}\text { Menit } \\
\text { ke-90 }\end{array}$} & & \\
\hline & & & $\begin{array}{c}\text { Kadar } \\
\text { Gula }\end{array}$ & Penurunan & $\begin{array}{c}\text { Kadar } \\
\text { Gula }\end{array}$ & Penurunan & $\begin{array}{c}\text { Kadar } \\
\text { Gula }\end{array}$ & Penurunan & $\begin{array}{c}\text { Kadar } \\
\text { Gula }\end{array}$ & Penurunan \\
\hline $\begin{array}{l}\text { Kontrol Negatif } \\
\text { (Na-CMC) }\end{array}$ & 95,6 & 118,4 & 120,6 & 0 & 119,4 & 0 & 116,2 & 2,2 & 111 & 7,4 \\
\hline $\begin{array}{l}\text { Kontrol Positif } \\
\text { (Glibenklamid } 5 \mathrm{mg} \text { ) }\end{array}$ & 122 & 138,4 & 120,4 & 18 & 106,8 & 31,6 & 91,6 & 46,8 & 64,2 & 74,2 \\
\hline Dosis $420 \mathrm{mg}$ & 98 & 137 & 128,2 & 8,8 & 116 & 21 & $101,6^{*}$ & 35,4 & $88^{*}$ & 49 \\
\hline Dosis $840 \mathrm{mg}$ & 126,2 & 150 & 144,4 & 5,6 & 139,2 & 10,8 & 132,2 & 17,8 & 109,6 & 40,4 \\
\hline Dosis $1260 \mathrm{mg}$ & 104,4 & 132,6 & 127 & $\overline{5,6}$ & 118,4 & 14,2 & 110,8 & 21,8 & 106,2 & 26,4 \\
\hline
\end{tabular}

* $p$ value $\leq 0,05$

Setelah itu dilakukan uji Post Hoc Duncan untuk mengetahui dosis terbaik dari infusa daun insulin terhadap penurunan kadar glukosa darah pada mencit. Hasil uji Post Hoc Duncan menunjukkan bahwa Infusa Daun Insulin $420 \mathrm{mg}$ adalah dosis terbaik yang memiliki efek penurunan kadar glukosa darah, kemudian diikuti dengan Infusa Daun Insulin $1260 \mathrm{mg}$ dan $840 \mathrm{mg}$ yang sudah memiliki efek antihiperglikemia tetapi belum terlihat perbedaan yang signifikan.

Hasil penelitian ini sejalan dengan hasil yang diperoleh pada penelitian sebelumnya yang dilakukan oleh Stevani $\mathrm{dkk}^{10}$ yang menunjukkan bahwa rebusan daun kersen atau insulin pada konsentrasi $10 \%$ dan $15 \%$ dapat menurunkan kadar glukosa darah pada mencit dan penurunan kadar glukosa maksimal terjadi pada menit ke 120.

Berdasarkan penelitian sebelumnya yang dilakukan oleh Mila Karmila $\mathrm{S}^{8}$ menunjukkan bahwa rebusan daun Insulin Pada dosis $3 \mathrm{~g} / \mathrm{kgBB}$ tikus dapat menurunkan kadar glukosa darah pada tikus dan penurunan kadar glukosa maksimal terjadi pada menit ke-120.

Hasil yang diperoleh dari penelitian ini sama juga menunjukkan hasil yang serupa dengan penelitian sebelumnya, yaitu infusa daun insulin yang efektif untuk menurunkan kadar glukosa darah pada mencit adalah infusa daun insulin $420 \mathrm{mg} / \mathrm{kgBB}$ mencit dari pengkonversian dosis tikus ke mencit, serta penurunan kadar glukosa yang maksimal pada menit ke-90 dan menit ke-120. ${ }^{11,12,13}$

Sedangkan pada penelitian yang lain, yang dilakukan oleh Widihastuti ${ }^{14}$ menunjukkan bahwa ekstrak etanol daun insulin dapat digunakan sebagai antihiperglikemik dengan dosis efektif $21 \mathrm{mg} / 20 \mathrm{~g} \mathrm{BB}$.

Lalu pada penelitian Sari ${ }^{15}$ menunjukkan bahwa infusa daun paitan atau insulin (Tithonia diversifolia (Hemsl.) A. Gray) $8 \%$ dapat 
memberikan efek antidiabetes pada tikus diabetes yang terinduksi Streptozotosin.

Pada kelompok obat dapat menurunkan kadar glukosa darah karena glibenklamid memiliki mekanisme kerja merangsang sekresi insulin dari pankreas, menghambat ATP sensitve potasium channel di sel $\beta$ pankreas sehingga membantu untuk mengurangi jumlah gula dalam darah seseorang, mengurangi kadar glukogen dalam serum dan meningkatkan pengikatan insulin pada jaringan target dan reseptor. Sedangkan pada kelompok ekstrak dapat menurunkan kadar glukosa darah karena ekstrak etanol daun insulin mengandung flavonoid, saponin. ${ }^{16,17,18}$

Flavonoid pada DM dapat menghindari absorpsi gula, menstimulasi pengambilan glukosa pada jaringan perifer, juga dapat bertindak seperti insulin dengan cara mempengaruhi mekanisme insulin signaling. Mekanisme kerja saponin yaitu dengan menghambat GLUT-1 sehingga menurunkan absorbsi glukosa. Flavonoid dapat meningkatkan penggunaan glukosa di jaringan perifer dan mengurangi resistensi insulin, inflamasi serta stress oksidatif pada otot dan lemak. ${ }^{19,20}$ Senyawa saponin dapat meningkatkan sensitivitas insulin, menghambat gluconeogenesis dan meningkatkan ekspresi Glucose Transporter 4 (GLUT-4). ${ }^{20}$

\section{KESIMPULAN}

Berdasarkan hasil penelitian dan analisis data yang telah dilakukan pada penelitian tentang uji efektivitas infusa daun insulin (Tithonia diversifolia (Hems.) A.Gray) terhadap penurunan glukosa darah pada mencit, dapat disimpulkan bahwa dosis infusa daun insulin (Tithonia diversifolia (Hems.) A. Gray) yang efektif dalam menurunkan kadar glukosa darah pada mencit (Mus musculus) adalah pada dosis $420 \mathrm{mg}$ dengan penurunan kadar glukosa maksimal pada menit ke-90 dan menit ke-120. Dosis 1260 mg dan $480 \mathrm{mg}$ sudah memiliki efek antihiperglikemia tetapi belum terlihat perbedaan yang signifikan.

Untuk peneliti selanjutnya perlu dilakukan penelitian lebih lanjut untuk infusa daun insulin dengan menggunakan metode yang berbeda seperti metode ekstrak.

\section{DAFTAR PUSTAKA}

1. Katzung, Bertram G., and Anthony J. Trevor, $14^{\text {th }}$ eds. Basic \& clinical pharmacology. Boston: McGraw-Hill Education. 2015.

2. American Diabetes Association. 2. Classification and diagnosis of diabetes: standards of medical care in diabetes-2019. Diabetes Care. 2019; 42(Supplement 1): S13-S28

3. Rahmawati, S. Efektivitas Ekstrak Kulit Batang, Akar, dan Daun Sirsak (Annona mucirata L.) Terhadap Kadar Glukosa Darah, Skripsi, 3, Universitas Islam Negeri Sunan Kalijaga, Yogyakarta. 2013

4. Ejelonu OC, Elekofehinti OO, Adanlawo IG. Tithonia diversifolia saponin-blood lipid interaction and its influence on immune system of normal wistar rats. Biomedicine \& Pharmacotherapy. 2017 Mar 1;87:589-95.

5. Blasiak J., et al. Free Radical Scavengers Can Modulate the DNA-Damaging Action of Alloxan. Acta Biocem, 2003; 50 (1): 205-10.

6. Geethaa, Saghal, Ramanathan, S., et all. Brine Shrimp Lethality and Acute Oral Toxicity Studies on Swetenia Mahagoni (Linn) Jacq. Seed Methanolic Extract. Pharmacognosy Research. 2010; 2 (4): 215-220.

7. Dalimartha, S. Ramuan Tradisional Untuk Pengobatan Diabetes Mellitus. Penerbit Penebar Swadaya, Bogor. 2005.

8. Mila Karmila Sri Setiomulyo. Pengaruh Air Rebusan Daun Insulin (Tithonia diversifolia (Hemsl.) A. Gray) Terhadap Kadar Glukosa Darah Tikus Jantan Galur Wistar yang Terbebani Glukosa. Skripsi Program Stusi Farmasi, Universitas Sanata Dharma, Yogyakarta. 2016.

9. Sani K, Fathnur. Metodologi Penelitian Farmasi Komunitas dan Eksperimental. Edisi 1 cetakan 1. Yogyakarta: Deepublish. 2016.

10. Stevani, H., Nurul, H.B., Husnul, A.T. "Efektivitas Rebusan Daun Kersen (Muntingia calabura L.) Terhadap Penurunan Kadar Glukosa Darah Pada Mencit (Mus musculus). E-journal : Poltekkes Kemenkes Makassar, Akademi Farmasi Yamasi Makassar. 2017.

11. Apriyanti, Erna. Efek Ekstrak Etanol Daun Kersen (Muntingia calabura L.) Terhadap Penghambatan Peningkatan Kadar Gula Darah Pada Tikus Putih Jantan Galur Wistar. Skripsi Progaram Studi Ilmu Farmasi,Sekolah Tinggi Ilmu Kesehatan Ngudi Waluyo, Ungaran. 2016.

12. Azmi Agnia. Efek Ekstrak Daun Insulin (Smallanthus sonchifolius) Terhadap Kadar Glukosa Darah, Berat Badan dan Low Density Lipoprotein Pada Tikus yang Diinduksi Streptozotosin. Skripsi Program Studi Kedokteran, Universitas Islam Negeri Syarif Hidayatullah, Jakarta. 2015.

13. Song, Y., Joann, E.M., Jullie E.B., Howard, D.S., Simin, L. Association of Dietary Flavanoids with Risk of Thype 2 Diabetes, and Markers of Insulin Resistance and Systemic Inflammation in Women: A Prospective Study and Cross-Sectional 
Analysis, Journal of the American College of Nutrition. 2005; 24(5).

14. Widihastuti, Tantri. Uji Aktivitas Antihiperglikemik Ekstrak Etanol Daun Insulin (Tithonia diversifolia Gray) Terhadap Mencit Putih Jantan (Mus musculus) Dengan Metode Toleransi Glukosa. KTI Program Studi Farmasi, Universitas Setia Budi, Surakarta. 2017.

15. Sari, Ajeng Dwi Kartika. Efek Antidiabetes Infusa Daun Paitan (Tithonia diversifolia) $8 \%$ Terhadap Tikus Putih Jantan Galur Wistar Terinduksi Streptozotosin. Skripsi Program Studi Farmasi, Universitas Sanata Dharma, Yogyakarta. 2017.

16. Prasetyo A, Denashurya TG, Putri WS, In'am Ilmiawan M. Perbandingan Efek Hipoglikemik Infusa Daun Kembang Bulan (Tithonia diversifolia (Hamsley) A. Gray) dan Metformin pada Tikus yang Diinduksi Aloksan. Cermin Dunia Kedokteran. 2016 Feb 1;43(2):91-4.

17. Gbolade, A.A., Biondi, D.M., Ruberto, G. Comparative Analysis of The Essential Oil from Two Asteraceous Plants Found in Nigeria, Acanthospermum hispidum and Tithonia diversifolia. Nat. Prod. Commun. 2008; 3(10): 1735-1738.

18. Miura, T., Nosaka, K., Ishii, H., and Ishida, T. Antidiabetic Effect of Nitobegiku, The Herb Tithonia diversifolia, in KK-Ay Diabetic Mice. Pharmaceutical Society of Japan, Japan. 2005; 28(11): 2152-2154.

19. Jadhav, R., and Puchchakayala, G. Hypoglycemic and Antidiabetic Activity Flavonoids: Boswellic Acid, Ellagic Acid, Quercetin, Rutin on Streptozotocin-Nicotinamide Induced Type 2 Diabetic Rats. International Journal of Pharmacy and Pharmaceutical Sciences. 2012; 4(2): 251256.

20. Bhavsar, S.K., Singh, S., Giri, S., Jain, M.R., and Santani, D.D. Effect of Saponins From Helicteres isora on Lipid and Glucose Metabolism Regulating Genes Expression. Journal Ethnopharmacol. 2009; 124(3): 426-433. 